\title{
A major shift to the retention approach for forestry can help resolve some global forest sustainability issues
}

D.B. Lindenmayer ${ }^{1}$, J.F. Franklin ${ }^{2}$, A. Lõhmus ${ }^{3}$, S.C. Baker ${ }^{4}$, J. Bauhus ${ }^{5}$, W. Beese ${ }^{6}$, A. Brodie ${ }^{7}$, B. Kiehl ${ }^{8}$, J. Kouki ${ }^{9}$, G. Martínez Pastur ${ }^{10}$, C. Messier ${ }^{11}$, M. Neyland ${ }^{12}$, B. Palik ${ }^{13}$, A. Sverdrup-Thygeson ${ }^{14}$, J. Volney ${ }^{15}$, A. Wayne ${ }^{16}$, \& L. Gustafsson ${ }^{8}$

${ }^{1}$ Fenner School of Environment and Society and ARC Centre of Excellence for Environmental Decisions, The Australian National University, Canberra, ACT 0200, Australia

${ }^{2}$ School of Environmental and Forest Science, College of the Environment, University of Washington, Seattle, Washington, DC 98195, USA

3 Institute of Ecology and Earth Sciences, University of Tartu, Vanemuise 46, EE-51014 Tartu, Estonia

${ }^{4}$ School of Plant Science, University of Tasmania, Hobart, Tasmania 7001, Australia

${ }^{5}$ Institute of Silviculture, University of Freiburg, Tennenbacherstr. 4, 79085 Freiburg, Germany

${ }^{6}$ Forestry Department, Faculty of Science and Technology, Vancouver Island University, 900 Fifth Street, Nanaimo, BC V9R 5S5, Canada

${ }^{7}$ Forest Resources and Conservation Division, Washington State Department of Natural Resources, 1111 Washington St SE, P. O. Box 47016, Olympia, Washington, WA 98501, USA

${ }^{8}$ Swedish University of Agricultural Sciences, Department of Ecology, P.O. Box 7044, SE-750 07 Uppsala, Sweden

${ }^{9}$ School of Forest Sciences, University of Eastern Finland-Joensuu, P.O. Box 111 (Yliopistokatu 7), Fl-80101 Joensuu, Finland

${ }^{10}$ Centro Austral de Investigaciones Científicas (CADIC CONICET), Houssay 200 (9410) Ushuaia, Tierra del Fuego, Argentina

${ }^{11}$ Département des Sciences Biologiques, Centre d’Étude de la Forêt (CEF), Université du Québec à Montréal (UQAM), C.P. 8888, Succ. Centre-Ville, Montréal, QC H2X 3Y5, Canada

${ }^{12}$ Forestry Tasmania, 79 Melville Street, Hobart, Tasmania 7000, Australia

${ }^{13}$ USDA Forest Service, Northern Forest Station, Grand Rapids, Minnesota, USA

${ }^{14}$ Norwegian University of Life Sciences, Department of Ecology and Natural Resource Management, P.O. Box 5003, NO-1432 Aas, Norway and Norwegian Institute for Nature Research (NINA), Gaustadalléen 21, NO-0349 Oslo, Norway, and Norwegian Institute for Nature Research (NINA), Gaustadalléen 21, NO-0349 Oslo, Norway

${ }^{15}$ Natural Resources Canada, Canadian Forest Service, Northern Forestry Centre, Edmonton, Alberta, Canada

${ }^{16}$ Department of Environment and Conservation, Locked Bag 2, Manjimup, WA 6258, Australia

\section{Keywords}

Ecologically sustainable forest management; altered logging practices; forest biodiversity conservation; forest ecosystem processes; altered forest policy; ecological forestry.

\section{Correspondence}

D.B. Lindenmayer, Fenner School of Environment and Society, The Australian National University, Canberra, ACT 0200, Australia.

Tel: +61-2-6125-0654;

fax: +61-2-6125-0757

E-mail: david.lindenmayer@anu.edu.au

Received

4 March 2012

Accepted

7 May 2012

Editor

Dr. Philip Levin

doi: 10.1111/j.1755-263X.2012.00257.x

\begin{abstract}
Approximately $85 \%$ of the global forest estate is neither formally protected nor in areas dedicated to intensive wood production (e.g., plantations). Given the spatial extent of unprotected forests, finding management approaches that will sustain their multiple environmental, economic, and cultural values and prevent their conversion to other uses is imperative. The major global challenge of native forest management is further demonstrated by ongoing steep declines in forest biodiversity and carbon stocks. Here, we suggest that an essential part of such management-supplementing the protection of large reserves and sensitive areas within forest landscapes (e.g., aquatic features) - is the adoption of the retention approach in forests where logging occurs. This ecological approach to harvesting provides for permanent retention of important selected structures (e.g., trees and decayed logs) to provide for continuity of ecosystem structure, function, and species composition in the postharvest forest. The retention approach supports the integration of environmental, economic, and cultural values and is broadly applicable to tropical, temperate, and boreal forests, adaptable to different management objectives, and appropriate in different societal settings. The widespread adoption of the retention approach would be one of the most significant changes in management practice since the onset of modern high-yield forestry.
\end{abstract}

\section{Introduction}

Sustainable practices and policies based on the best science are recognized as critical to the future of humankind
(Bettencourt \& Kaur 2011), but there is a large gap between the rhetoric and the reality of sustainability (Fischer et al. 2007). This is particularly apparent in the world's native and seminatural forest ecosystems that 
cover $30 \%$ of the earth's terrestrial environment. These forests are immensely important as a primary source of ecological goods and services essential to humankind (TEEB 2010) and are worth trillions of dollars annually (Millennium Ecosystem Assessment 2005). Unfortunately, many key values are threatened in these forests including forest biodiversity and forest carbon stocks, which are both declining steeply (Butchart et al. 2010; Saatchi et al. 2011). Management approaches that effectively integrate and maintain the environmental, economic, and cultural values of natural and seminatural forests (sensu FAO 2010) are clearly required and are not provided by past policies (Freer-Smith \& Carnus 2008).

Historically, foresters and other natural resource managers failed to provide well-defined scientifically sound approaches to integrate the maintenance of ecosystem functions, biodiversity, wood production, and cultural values. In practice, attempts to simultaneously provide for such values, such as "multiple-use forestry," utilized land allocations with primary use emphases, such as for intensive wood production, recreation, or wildlife habitat (reviewed by Lindenmayer \& Franklin (2002). Moreover, traditional forest management assumed that wood production had primacy over other values (Puettmann et al. 2008).

We define ecologically sustainable forest management (ESFM) as forest management that perpetuates ecosystem integrity while providing wood and nonwood values; where ecosystem integrity means the maintenance of forest structural complexity, species diversity and composition, and ecological processes and functions within the bounds of normal disturbance regimes. We argue that the global challenge of developing ESFM requires diverse, multiscaled approaches (Figure 1). These include: protection of sensitive areas within managed landscapes, such as riparian zones (Clinton 2011) and cultural sites (Bhagwat \& Rutte 2006); restoration of appropriate forest and landscape conditions (Lamb 2011); and maintenance of key ecological processes (e.g., fire regimes) (Figure 1).

In this article, we argue that truly sustainable forest management practices require a shift from traditional logging practices (such as those based on clear-cutting as well as the recurrent application of selection systems) to the much wider use of the retention approach to forest harvesting. Traditional practices can have major negative impacts on ecological and cultural goals, such as by structurally and functionally simplifying forests. In retention harvesting, significant elements of the original forest (e.g., structures, organisms, and patches) are retained permanently when the forest is logged to enrich the postharvest forest in the long term. The retention ap- proach has intensively been tested and more than two decades of scientific study demonstrate its potential for application in the vast majority of the world's tropical, temperate, and boreal forests where logging takes place, regardless of markedly different disturbance regimes, biotic communities, and ownerships.

We contend that it is critical to change policies and practices to incorporate the retention approach as part of a multiscaled strategy for ESFM. The adoption of the retention approach within forests that are logged is important for: (1) maintaining multiple forest values and societal expectations of the global forest estate and (2) generating economic benefits for governments, private landowners, and trust managers. Realizing these multiple benefits is essential to prevent conversion of millions of hectares of forest annually (FAO 2010; Supplementary Information S3) to such other uses as tree plantations, agriculture (e.g., Oil Palm Elaeis guineensis cultivation), and built environments, with corresponding losses of biodiversity and ecosystem services (Putz et al. 2008; Smith et al. 2010). We argue that widespread adoption of retention harvesting is essential to enable balanced consideration of ecological, economic, and cultural values of forests and to provide a blueprint for ESFM (see Figure 1).

\section{The critical need for ecologically sustainable forest management and the retention approach}

ESFM (with retention harvesting as a key element of an array of multiscaled approaches) is critical because approximately $85 \%$ of the global forest estate is neither formally protected nor dedicated to intensive wood production (e.g., plantations); nor is most of it likely to be committed to either of these objectives. Indeed, 2 billion hectares, or $55 \%$, of the global forest estate is currently (and will continue to be) managed for multiple environmental, economic, and cultural values (FAO 2010). Finding ways to sustain these forests is imperative given their great extent and the array of critical goods and services that they provide to human society (Edwards et al. 2010). Partitioning them into either protected areas or plantations will often not be a realistic land use option.

Protected areas cover $11 \%$ of the world's forest area (Table S2) and they are managed primarily to conserve biodiversity and some key ecosystem processes. They are important, but protected areas alone will not support viable and well-distributed populations of many forestdependent species (Mascia \& Pailler 2011). In addition, 


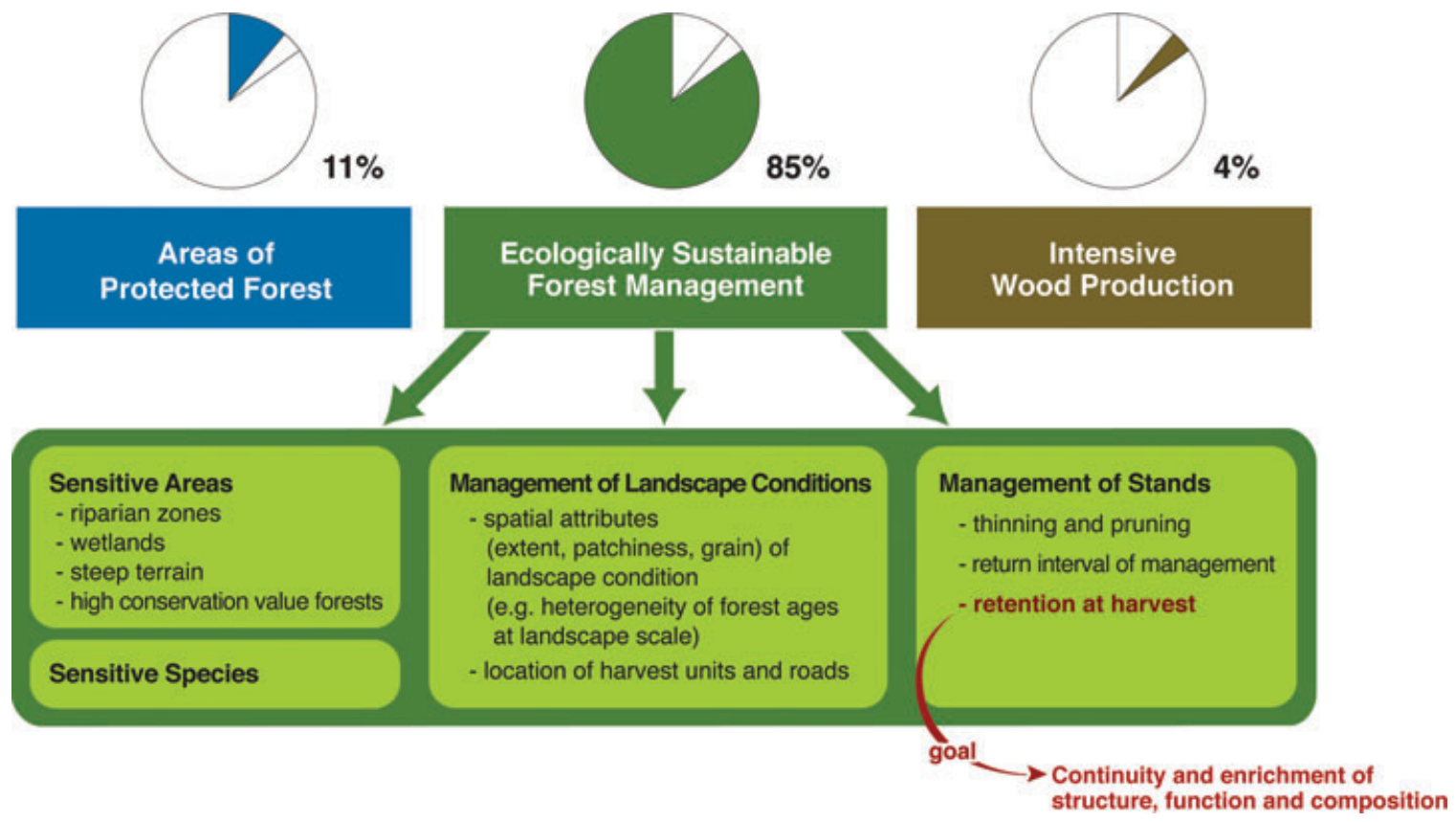

Figure 1 The global forest estate (\% of area) based on dominant management paradigms: reservation, intensive wood production, and ESFM. We list some management approaches (e.g., the protection of sensitive areas) that can be used to achieve environmental, economic, and cultural

protected area status may not always slow the rates of deforestation or losses of forest cover (Porter-Bolland et al. 2012). Finally-and importantly-the majority of the global forest estate is owned by individuals, trusts, and governments who require some kind of financial return; strict preservation of these forests will be limited.

Intensive wood production areas, exemplified by plantations (defined in Supplementary Information S1), are managed primarily for high financial returns from efficient production of wood (e.g., "industrial roundwood"; Bauhus et al. 2010). While these areas contribute disproportionately to global wood supply (FAO 2010), many important environmental and social values are marginalized (Cao 2008).

Together, protected areas and areas dedicated to plantations for intensive timber production currently comprise $\sim 15 \%$ of global forests (Figure 2; Supplementary Information S2) (FAO 2010). This is unlikely to increase to more than a quarter of the total global forest area because of social factors (including land ownership) and economic factors (Schmitt et al. 2009; Bauhus et al. 2010). This leaves the vast majority of the world's forests in areas where the forests will either be managed for multiple values, converted to other uses, or abandoned. In the remainder of this article, we outline how management us- objectives in forests under ESFM. Of these, the retention approach is the focus of this article and one of a number of key strategies to be applied in attempts to achieve ESFM.

ing retention harvesting and other ecologically based approaches can allow native and seminatural forests to be managed simultaneously for environmental, economic, and cultural values.

\section{The retention approach}

We define the retention approach as:

An approach to forest management based on the long-term retention of structures and organisms, such as live and dead trees and small areas of intact forest, at the time of harvest. These structures and organisms are not removed in future forest management operations and hence undergo natural processes of growth and decay. The aim is to achieve a significant level of continuity in forest structure, composition, and complexity that promotes maintenance of biodiversity and ecological functions at different spatial scales. Approaches and levels of retention, which take account of natural disturbance dynamics, differ depending on local context but the practice is appropriate for all types of silvicultural systems and forests.

A key aspect of the above definition is the emphasis on long-term retention of structures or small forest patches, which distinguishes the retention approach from conventional, uneven-aged selection management or even-aged 


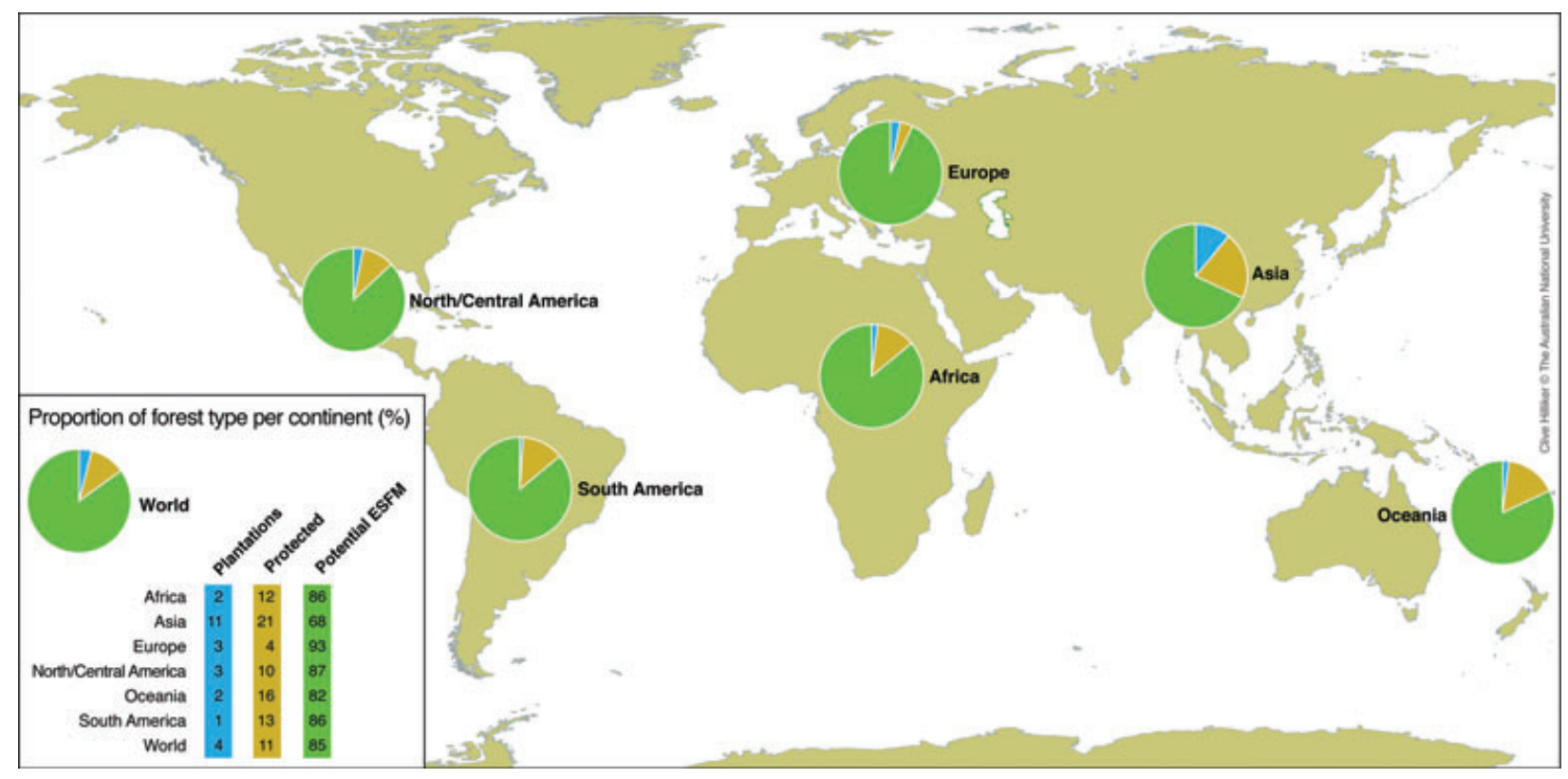

Figure 2 Map of the world's major forests with pie charts representing proportions of the regional forest area of reserves, intensively managed wood production forests (primarily plantations; defined in Supporting Information S1) and forests with potential for ESFM. The latter correspond to the area where the retention approach is needed as one of a suite of approaches for ESFM. Based on data in Saatchi et al. (2011).

shelterwood and seed tree systems (sensu Helms 1998); these silvicultural approaches ultimately remove trees retained during initial harvesting operations during subsequent stand entries. A second key element distinguishing the retention approach from essentially all other traditional forest harvesting is that there is as much or more emphasis on what is retained as opposed to what is removed during harvesting (Franklin et al. 1997).

The retention approach is based on a large and rapidly expanding body of scientific evidence gathered over two decades (Figure 3). A web search on August 30, 2011 revealed $\sim 1,360$ peer-reviewed articles on retention harvesting from around the world (see Supplementary Information S4). Our search spanned temperate and boreal environments and expanded upon the extensive reviews by Rosenvald \& Lõhmus (2008) and Gustafsson et al. (2010). We extended our search to include reducedimpact logging (RIL) and selective logging studies in tropical regions in which long-term retention of forest structural attributes was a key part of the research (e.g., biodiversity conservation (Eltz et al. 2003) and maintenance of key ecosystem functions (Putz et al. 2008)). Indeed, there are examples of long-term retention of key stand components within RIL systems in managed tropical forests on different continents (Sheil et al. 2010).

More than 470 studies examined relationships between retention levels and biodiversity (Supplementary Information S4). This research has underscored the value of the retention approach in promoting the conservation of biotic groups ranging from mammals and birds (e.g., Vanderwel et al. 2007; Lindenmayer et al. 2010) through understorey and other plant species (Baker $\&$ Read 2011) to invertebrates, soil biota, and mycorrhizal fungi (Martikainen et al. 2006; Outerbridge \& Trofymow 2009). Much research has also highlighted those management approaches most effective in the long-term maintenance of key-retained structures such as large and old trees (Gibbons et al. 2010). The ability of retention harvesting to produce economically viable timber yields has been demonstrated in many studies, although yields are sometimes reduced in some cases (Nyvold et al. 2005), but equivalent to those from conventional but more environmentally damaging logging systems in other cases (e.g., Holmes et al. 2002, Jakobsson and Elfving 2004; see Figure 3).

Retention harvesting has been shown to have higher levels of social acceptability than traditional harvesting methods (Ribe 2005; Putz et al. 2008). This may result in an increased social licence to harvest timber because the increased ecological and biodiversity benefits outweigh the additional costs of, and/or reductions in, timber yields. However, such a social licence should not be used as a justification for logging of high conservation value forests or previously unlogged forests, nor undermine the case for strict protection of areas that support highly disturbance-sensitive species or key ecological 


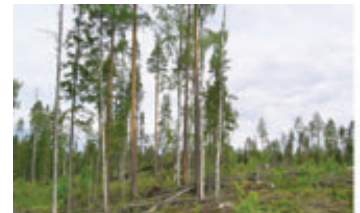

A. Biodiversity

Tree retention mitigates harvesting impacts on beetle assemblages

(Hyvarinen et al., 2009)

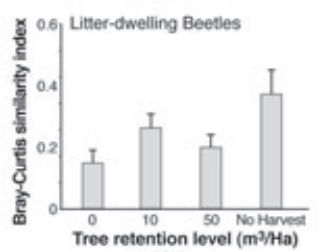

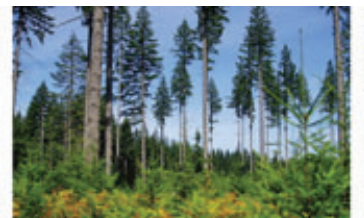

B. Social Acceptability

Dispersed tree retention is more socially acceptable than aggregated retention (Ribe 2005)

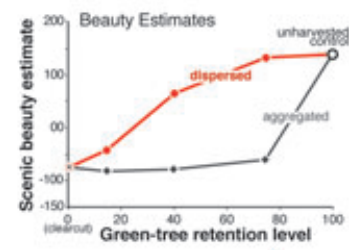

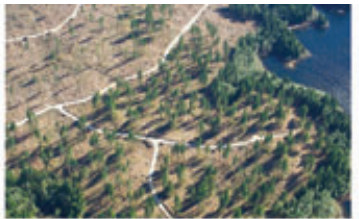

C. Ecological Function

Tree retention maintains ectomycorrhiza in harvested stands

(Outerbridge and Trofymow 2009)

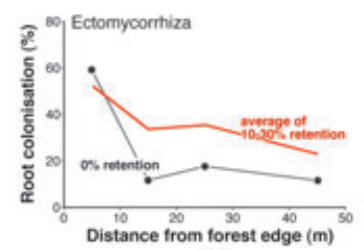

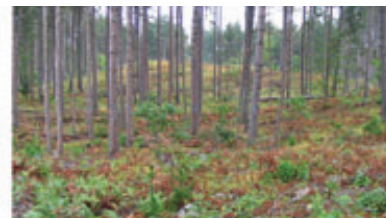

D. Growth \& Productivity

At the same retention levels there is no difference in new cohort (seedling) productivity (Powers et al., 2011)
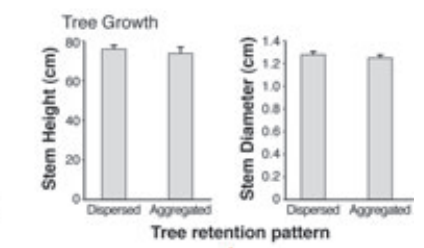

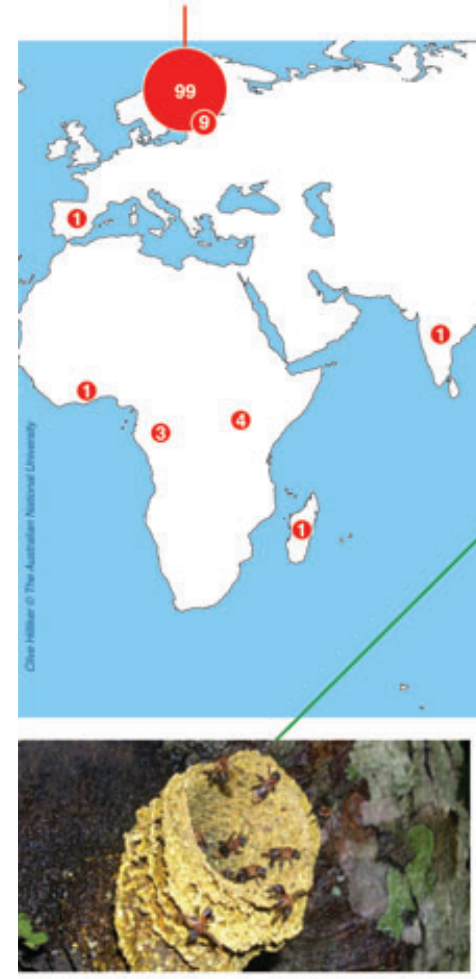

\section{E. Biodiversity}

Tree retention promotes the maintenance of stingless bee populations in reducedimpact logged rainforest. (Elzet al, 2003)

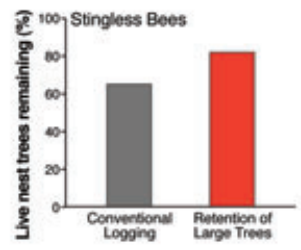

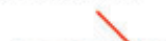
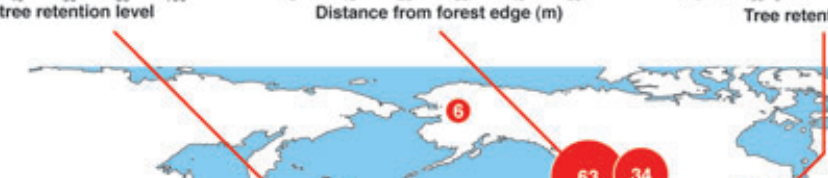

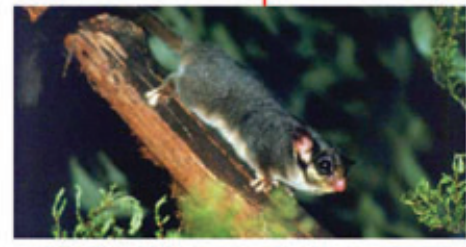

\section{F. Biodiversity}

Retention levels on logged sites affect probability of colonization by

Leadbeaters Possum after only 10 years (Lindenmayer et al. 1991, 2011)

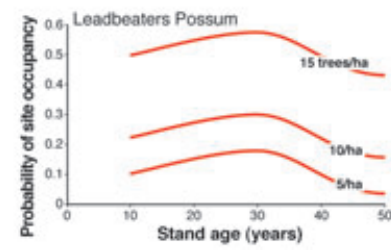

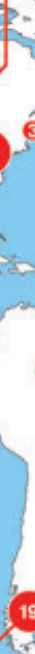
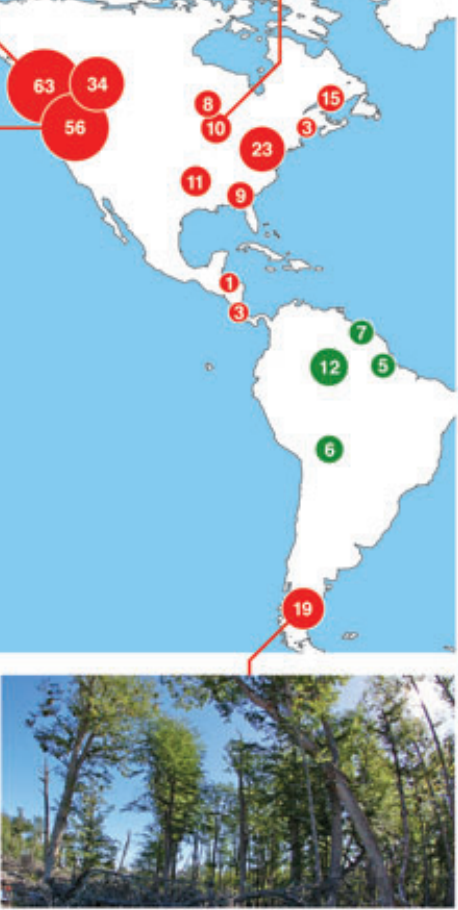

\section{G. Economics}

At the same retention levels, retention harvesting gives the same economic return as traditional shelterwood harvesting (Martinez Pastur et al., 2009)

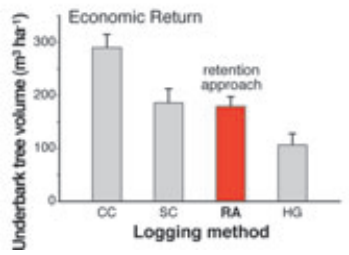

Figure 3 Locations of major studies of the retention approach in temperate and boreal regions (red dots) and tropical ecosystems (green dots) where biodiversity conservation and the maintenance of key ecosystem processes are part of long-term retention within RIL and selection logging operations 
processes (see the section below on caveats and knowledge gaps).

\section{Entities targeted for retention}

Common elements of preharvest forests targeted for long-term retention include individual structures (such as large living or dead trees, cavity trees, and logs) (Rosenvald \& Lõhmus 2008), organisms (e.g., particular plant species), and small (typically 0.1-1 hectare) intact forest areas incorporating undisturbed ground-cover vegetation and forest floors (Figure 3).

Scientific knowledge of the biological legacies (sensu Franklin et al. 2000) created by natural disturbances provides a guide for the types, quantities, and spatial distribution of structures and organisms appropriate for retention. Using natural disturbance regimes as a model for human-induced disturbances, such as timber harvesting, dates back more than a century (e.g., Gayer 1886). The underlying premise is that species are likely to be adapted to disturbance regimes with which they evolved, but not necessarily to novel disturbances. Relating this premise to retention harvesting, understanding the types, numbers, and spatial patterns of living and dead trees and microhabitats that remain after natural disturbances, such as wildfires or windstorms, can help guide selection of legacies for retention to better conserve biodiversity and maintain key ecological processes following timber harvesting (Franklin et al. 2000). Hence, when retention harvesting is applied on-the-ground, it can be designed to broadly reflect the variability in natural disturbance regimes.

\section{Broad goals of the retention approach}

The retention approach has three primary goals. These are: (1) providing for continuity of structure, function, and composition between the generations (preharvest and postharvest) of forest ecosystems; (2) structurally and functionally enriching forest ecosystems that develop following harvesting; and (3) facilitating landscape connectivity, including the movement of disturbance-sensitive biota (Franklin et al. 1997). Details of retention harvesting prescriptions will vary among forest ecosystems (Figure 3) reflecting their natural histories, including their disturbance dynamics, stand composition and condition, and landscape context. Other important variables include specific management objectives and integration of retention with other ecologically oriented management approaches, such as riparian protection (Figure 1; Clinton 2011).

The retention approach can readily be integrated with all current forms of silviculture including single tree and group selection, RIL, and even-aged systems such as shelterwood, seed-tree, and clear-cutting. The retention approach can also be applied in other management practices within established stands, such as thinning (Roccaforte et al. 2010). The retention approach provides distinct opportunities for the establishment of regeneration including regeneration of shade-tolerant plant species (Baker $\delta$ Read 2011).

\section{Caveats and knowledge gaps associated with the application of the retention approach}

We argue that any kind of timber harvesting-including the retention approach-may be inappropriate within areas of high conservation value forest (Figure 1), which may require strict protection from human disturbances (Gibson et al. 2011). Hence, we do not advocate the retention approach as a justification for entering previously unlogged native forest. Indeed, we

(Continued) (see Supplementary Information S3). The size of the dots reflects the relative study effort in a given region with numbers of published studies indicated. The graphs show selected examples of various kinds of effects associated with retention. Bars on graphs include \pm standard deviation. (A) Response of beetle assemblages to clear-cut versus retention logging in northern Europe. The $y$-axis is a Bray-Curtis similarity index comparing pretreatment litter-dwelling beetle assemblages with those 2 years posttreatment (redrawn from Hyvärinen et al. (2006)) (Photo by J. Kouki). (B) Social acceptability of dispersed retention versus aggregated retention logging in western USA (Ribe 2005) (Photo by J. Franklin). (C) Ectomycorrhizal root colonization of trees in coastal British Columbia, Canada, with no retention and 5\%, 10\%, and 30\% retention (redrawn from Outerbridge \& Trofymow (2009) (Photo by W. Beese). (D) Mean (+ SE) seedling stem diameters and heights in Pinus resinosa forests harvested with dispersed retention and aggregated retention. Values are based on a composite of seedlings from species ranging from very shade intolerant to midtolerant. $N=4$ treatment stands for each bar (Powers et al. 2011) (Photo by B. Palik). (E) Proportion of living nest trees for stingless bees remaining following selection felling and after RIL with retention of large-diameter trees in Borneo (modified from Eltz et al. (2003)) (Photo by G. Fredriksson). (F) Temporal changes in the probability of occurrence of Gymnobelideus leadbeateri on logged sites with retention levels of 5, 10, and 15 cavity trees per ha in Victoria, Australia (based on data in Lindenmayer et al. (1991; 2011)). Note that animals do not occur in stands until 10 years after logging (Photo by D. Lindenmayer). (G) Economic returns (based on underbark timber volume) in South Patagonia, Argentina, from $\mathrm{CC}=$ clear-cut harvesting; $\mathrm{SC}=$ shelterwood harvesting; $\mathrm{RA}=$ retention approach; HG = high grading harvesting (Pastur et al. 2009) (Photo by G. Martinez Pastur). 
encourage all forest stakeholders to acknowledge the essential role of large protected areas in maintaining biota and ecosystem processes that cannot otherwise be adequately conserved within forests managed for multiple purposes. Examples include disturbance-sensitive taxa (Schneider et al. 2010) and keystone ecological processes, such as infrequent but high-severity fire regimes (Lindenmayer et al. 2011). Large protected areas also provide "natural controls" for use in assessing the impacts of forest management practices (see Gibson et al. 2011).

Although the retention approach has been widely applied, we readily acknowledge that important knowledge gaps remain. For example, more work is required to better quantify the most appropriate spatial scales at which the retention approach should be applied, including quantification of the kinds of landscapes where it will be most effective (e.g., those with high versus low levels of unlogged forest cover). In addition, more work is needed on the costs and benefits of the retention approach relative to other kinds of strategies such as the land sparing approach (sensu Green et al. 2005; see below). This would entail contrasting levels of biodiversity and the integrity of ecosystem processes in extensive areas subject to retention harvesting versus landscape mosaics (sensu Bennett et al. 2006) composed of mixtures of intensively logged and unlogged forest. This work is important because, for a given level of timber yield, widespread application of the retention approach may require more areas to be logged than when some places are intensively logged and others are strictly protected. This may, in turn, have the potential to negatively affect some key ecological processes and some elements of the biota (Franklin \& Forman 1987).

\section{Land sharing versus land sparing}

The retention approach is consistent with a land-sharing approach to land management where production and environmental goals such as biodiversity conservation are integrated in the same location (Green et al. 2005). Land sparing is the alternative model where intensive forest management to produce high yields is adopted in some areas as offsets for increased areas dedicated to conservation (Fischer et al. 2008). Essentially, land sparing is a continuation of traditional land-allocation approaches in which areas are committed to primary land uses, such as intensive production (e.g., plantations) versus biodiversity conservation (e.g., large ecological reserves). However, recent proposals for land sparing are novel in that they call for integration of intensification and reservation through better governance and regulation (Phalan et al. 2011 ; Lindenmayer et al. 2012).
The relative merits of land sparing versus land sharing have extensively been debated, particularly in agricultural landscapes (e.g., Fischer et al. 2008; Phalan et al. $2011)$. Such debates also have a long history in forestry (e.g., Gladstone \& Ledig 1990) with some authors arguing that shifts to intensive wood production (e.g., tree plantations) in some areas could create opportunities for an expanded forest reserve system elsewhere (Paquette \& Messier 2010). We also note that elements of both approaches may be appropriate within a region, for example, through zoning for forest management (e.g., Côté et al. 2010). Indeed, all land-sharing approaches require sparing at some level, and hence scale issues are important.

Several important factors need to be considered in decisions about land sparing versus land sharing. For example, those arguing against land sparing suggest that: (1) although offsets are possible in theory, the offsets usually are not made in practice-i.e., no additional lands are conserved (Ewers et al. 2009); and (2) key ecosystem processes, such as those that sustain productivity, can be compromised by intensive cropping of lands. Conversely, those arguing against land sharing contend that integrated approaches compromise both conservation and production goals, and reduced commodity production in land-spared landscapes can drive intensification in other landscapes.

We suggest that evaluations of the potential of the retention approach within a land sharing versus land sparing framework should be guided by: (1) management objectives; (2) the qualities of the forests proposed for intensive management and conservation; (3) the extent, representativeness, and distribution of the current system of protected areas; (4) the array of species of management concern and their mobility, distribution, and other attributes (e.g., see Ranius \& Roberge 2011); and (5) the relationships between conservation values (where they can be calculated) and economic revenues (Green et al. 2005).

Decisions about the merits of land sparing versus land sharing should also depend upon the landscape context and scale and ultimately guided by an assessment of the relative costs of production versus environmental risks and benefits at multiple (local, landscape, national, and global) spatial scales. Finally, we note that most land sparing/land sharing debates in the tropical regions have focused mainly on forest conversion to agricultural land. However, the focus of our arguments in this article are on the merits of the retention approach in maintaining multiple environmental, economic, and cultural values relative to conventional harvesting systems, such as clearcutting or selective logging, in more or less permanently forested landscapes. 


\section{A global shift to the retention approach}

Standards, principles, and criteria for ESFM have been proposed in numerous initiatives over the past two decades. Examples (among many) include the Montreal, Tarapoto, and MCPFE processes (McDermott et al. 2010). Similarly, numerous protocols and standards within various certification schemes have been created to guide sustainable management of native forests (e.g., Wintle $\delta$ Lindenmayer 2008), including their interactions with initiatives such as REDD (Merger et al. $2011)$.

Although these initiatives are important, we suggest that wider adoption of the retention approach in such initiatives and certification criteria would be a key policy change that would improve the ecologically sustainable management of forests. As outlined above, we do not advocate logging (including retention harvesting) in previously unharvested natural forests or in high conservation forests. Where logging is occurring in multiple use forest, we recommend wider adoption of the retention approach by governments, resource management agencies, and by private forest owners. For example, increased adoption of the general principles underpinning the retention approach, particularly long-term maintenance of key stand structures, would greatly improve RIL practices in tropical forests as already evidenced in some tropical regions of the world (Eltz et al. 2003; Ezzine de Blas \& Perez 2008; Blaser et al. 2011).

A major challenge to wide adoption of retention harvesting is that many stakeholders are currently unaware of this approach or may incorrectly believe that it is not relevant to their forest type or silvicultural system. In addition, many private forest owners seek compensation for the retention of merchantable trees for a public good. Greater efforts are required to broaden recognition of major strengths of the retention approach including its strong scientific underpinnings, suitability in most biogeographical contexts, adaptability to different arrays of management objectives, appropriateness in different societal settings, applicability to a broad array of ownerships (from private to national), and relevance to forest certification schemes.

We recognize that changes in policies, laws, regulations, and prescriptions will be required in some jurisdictions to allow (and to foster) implementation of the retention approach. For example, in Quebec and in parts of Russia, it is currently illegal to leave trees on logged sites. In British Columbia, it was necessary to pass new legislation recognizing the retention silvicultural system before the government would issue timber harvesting permits that used the new terminology (Beese et al. 2003). Policies that instigate and sustain robust monitoring and support- ive research are another important step that governments need to take.

In some places, monitoring and research have shown that retention levels need to be significantly increased to meet ecological goals, such as perpetuation of mature trees (Eltz et al. 2003; Gibbons et al. 2010; Gustafsson et al. 2010), or the conservation of disturbance-sensitive species (Work et al. 2010). In other areas, monitoring has highlighted a need for strengthened prescriptions to reduce damage to retained vegetation (Sist et al. 2003), promote regeneration of key plant species, or better protect rare species (Schulze et al. 2008).

Key stakeholders need to be aware that good governance (including effective regulation) is another essential prerequisite for the successful long-term application of the retention approach and, in turn, ESFM (Cundill $\&$ Fabricius 2010). Important drivers who encourage managers to conform to established principles of sustainable forest management have included public pressure, government regulation, and requirements for forest certification (McDermott et al. 2010).

\section{Conclusions}

The immense, multifaceted environmental, economic, and cultural values provided by forests led the UN Forest Forum to adopt Four Global Objectives, including: "enhancing forest-based economic, social, and environmental benefits: [and] increasing significantly the area of protected forests, and other areas of sustainably managed forests worldwide" (ECOSOC 2006). We assert that implementation of policies that encourage adoption and use of the retention approach would contribute significantly to meeting these objectives, as well as those of other international initiatives like the Convention on Biological Diversity for which integrated management of natural resources is critical (Smith \& Maltby 2003). We suggest that a global shift to the retention approach is particularly critical to provide financial incentives that can reduce the current scale of forest conversion- 14 million hectares annually (FAO 2010) (Supplementary Information S3)-to other land uses like agriculture (Smith et al. 2010). We contend that this would greatly improve the conservation of biodiversity and maintenance of key ecosystem processes in forests that are not in formally protected areas and that comprise by far the bulk of the forest estate worldwide (Figures 1 and 2; Tables S1 and S2). Global adoption of the retention approach in implementing sustainable forest management is critical to balancing the ecological, social, and economic values of forests; it would represent one of the most significant changes in forestry 
practice since the onset of modern high-yield forestry in the mid-20th century.

\section{Acknowledgments}

The research for this article was funded through "Future Forests," a multidisciplinary research program supported by the Foundation for Strategic Environmental Research (MISTRA), the Swedish Forestry Industry, the Swedish University of Agricultural Sciences (SLU), Umeå University, and the Forestry Research Institute of Sweden (Skogforsk). Anders Esselin facilitated the workshop where the article was prepared. We thank the Editor and two anonymous referees for a wide range of astute and thought-provoking comments that considerably improved an earlier version of this article.

\section{Supporting Information}

Additional Supporting Information may be found in the online version of this article:

S1: Definition of plantations.

S2: Source of data on plantations.

S3: Figure for conversion of forest for agriculture.

S4: Literature searches on retention harvesting.

Table S1: Data used for calculation of proportion plantations, protected forests, and potential ESFM forests in Figure 1 of the main article and S1 (1,000 hectares). For information on data sources, see $\mathrm{S} 2$.

Table S2: Proportion ( \%) per continent of plantations, protected forests, and potential ESFM forests presented in Figure 2 of the main article. Based on same data as in Table S1.

\section{References.}

Please note: Blackwell Publishing is not responsible for the content or functionality of any supporting materials supplied by the authors. Any queries (other than missing material) should be directed to the corresponding author for the article.

\section{References}

Baker, S.C. \& Read, S. (2011) Variable retention silviculture in Tasmania's wet forests-background and ecological evaluation. Aust Forestry 74, 218-232.

Bauhus, J., van der Meer, P. \& Kanninen, M. (2010) Ecosystem goods and services from plantation forests. Earthscan, London.

Beese, W.J., Dunsworth, B.G., Zielke, K. \& Bancroft, B. (2003) Maintaining attributes of old growth forests in coastal B.C. through variable retention. Forestry Chronicle 79, 570-578.

Bennett, A.F., Radford, J.Q. \& Haslem, A. (2006) Properties of land mosaics: implications for nature conservation in agricultural landscapes. Biol Conserv 133, 250-264.
Bettencourt, E.M. \& Kaur, J. (2011) Evolution and structure of sustainability science. Proc Natl Acad Sci USA 108, 19540-19545.

Bhagwat, S.A. \& Rutte, C. (2006) Sacred groves: potential for biodiversity management. Front Ecol Environ 4, 519-524.

Blaser, J., Sarre, A., Poore, D. \& Johnson, S. (2011) Status of tropical forest management 2011. International tropical timber organization technical series no 38. International Tropical Timber Organization, Yokohama, Japan.

Butchart, S.H.M., Walpole, M., Collen, B. et al. (2010) Global biodiversity: indicators of recent declines. Science 32, 1164-1168.

Cao, S. (2008) Why large-scale afforestation efforts in China has failed to solve the desertification problem. Environ Sci Technol 42, 1826-1831.

CIFOR. (2011) Typology of Planted Forests. In: CIFOR InfoBrief. p. 4. Center for International Forestry Research (CIFOR), Bogor, Indonesia.

Clinton, B.D. (2011) Stream water responses to timber harvest: riparian buffer width effectiveness. Forest Ecol Manage 261, 979-988.

Côté, P., Tittler, R., Messier, C., Kneeshaw, D.D., Fall, A. \& Fortin, M.-J. 2010. Comparing different forest zoning options for landscape-scale management of the boreal forest: possible benefits of the TRIAD. Forest Ecol Manage 259, 418-427.

Cundill, G. \& Fabricius, C. (2010) Monitoring the governance dimension of natural resource co-management. Ecol Soc 15 , 15: Available from: http://www.ecologyandsociety.org/vol/ iss1/art/. Accessed February 2012.

Del Lungo, A., Ball, J. \& Carle, J. (2006) Global Planted Forests Thematic Study: Results and Analysis. In: Planted Forests and Trees. Working Paper 38. FAO, Rome.

ECOSOC. (2006) United Nations Forum on Forests. Report of the sixth session, 27 May 2005 and 13 to 24 May 2006. E/2006/42; E/CN.18/2006/18.

Edwards, D.P., Larsen, T.H., Docherty, T.D. et al. (2010) Degraded lands worth protecting: the biological importance of Southeast Asia's repeatedly logged forests. Proc Roy Soc B 278, 82-90.

Eltz, T., Bruhl, C.A., Imiyabir, Z. \& Linsenmair, K.E. (2003) Nesting and nest trees of stingless bees (Apidae: Meliponini) in lowland dipterocarp forests in Sabah, Malaysia, with implications for forest management. Forest Ecol Manage 172, 301-313.

Ewers, R., Scharlemann, J.P., Balmford, A. \& Green, R.E. (2009) Do increases in agricultural yield spare land for nature? Global Change Biol 15, 1716-1726.

Ezzine de Blas, D. \& Ruiz Perez, M. (2008) Prospects for reduced impact logging in Central African logging concessions. Forest Ecol Manage 256, 1506-1516.

FAO. (2010) Global forest resources assessment 2010: main report. FAO, Rome. 
Fischer, J., Brosi, B., Daily, G. et al. (2008) Should agricultural policies encourage land sparing or wildlife-friendly farming? Front Ecol Environ 6, 380-385.

Fischer, J., Manning, A.D., Steffen, W. et al. (2007) Mind the sustainability gap. Trends Ecol Evol 22, 621-624.

Franklin, J.F., Berg, D.E., Thornburgh, D.A. \& Tappeiner, J.C. (1997) Alternative silvicultural approaches to timber harvest: variable retention harvest systems. Pages 111-139 in K.A. Kohm \& J.F. Franklin, editors. Creating a forestry for the 21st century. Island Press, Covelo, California.

Franklin, J.F. \& Forman, R.T. (1987) Creating landscape patterns by forest cutting: ecological consequences and principles. Landscape Ecol 1, 5-18.

Franklin, J.F., Lindenmayer, D.B., MacMahon, J.A. et al. (2000) Threads of continuity. Conserv Biol Pract 1, 8-16.

Freer-Smith, P. \& Carnus, J.-M. (2008) The sustainable management and protection of forests: analysis of the current position globally. Ambio 37, 254-262.

Gayer, K. (1886) Der gemischte Wald - seine Begründung and Pflege, insbesondere durch Horst- und Gruppenwirtschaft. Verlag Paul Parey, Berlin.

Gibbons, P., McElhinny, C. \& Lindenmayer, D.B. (2010) What strategies are effective for perpetuating structures provided by old trees in harvested forests? A case study on trees with hollows in south-eastern Australia. Forest Ecol Manage 260, 975-982.

Gibson, L., Lee, M.L., Koh, L.P. et al. (2011) Primary forests are irreplaceable for sustaining tropical biodiversity. Nature 478, 378-381.

Gladstone, W.T. \& Ledig, F.T. (1990) Reducing the pressure on natural forests through high-yield forestry. Forest Ecol Manage 35, 69-78.

Green, R.E., Connell, S.J., Scharlemann, J.P. \& Balmford, A. (2005) Farming and the fate of wild nature. Science 307, 550-555.

Gustafsson, L., Kouki, J. \& Sverdrup-Thygeson, A. (2010) Tree retention as a conservation measure in clearcut forests of northern Europe: a review of ecological consequences. Scand J Forest Res 25, 295-308.

Helms, J.A. (1998) The dictionary of forestry. Society of American Foresters, Bethesda, Maryland.

Holmes, T.P., Blate, G.M., Zweedec, J.C. et al. (2002) Financial and ecological indicators of reduced impact logging performance in the eastern Amazon. Forest Ecol Manage 163, 93-110.

Hyvärinen, E., Kouki, J. \& Martikainen, P. (2006) Fire and green-tree retention in conservation of red-listed and rare deadwood-dependent beetles in Finnish boreal forests. Conserv Biol 20, 1711-1719.

Jakobsson, R. \& Elfving, B. (2004) Development of an 80-year mixed stand with retained Pinus sylvestris in Northern Sweden. Forest Ecol Manage 194, 249-258.

Lamb, D. (2011) Regreening the bare hills: tropical forest regeneration in the Asia-Pacific region. Springer, Dordrecht, The Netherlands.
Lindenmayer, D.B., Cunningham, R.B., Tanton, M.T., Nix, H.A. \& Smith, A.P. (1991) The conservation of arboreal marsupials in the montane ash forests of the Central Highlands of Victoria, South-East Australia: III. The habitat requirements of Leadbeater's Possum Gymnobelideus leadbeateri and models of the diversity and abundance of arboreal marsupials. Biol Conserv 56, 295-315.

Lindenmayer, D.B., Cunningham, S.A. \& Young, A., editors. (2012). Land use intensification: effects on agriculture, biodiversity and ecological processes. CSIRO Publishing, Melbourne.

Lindenmayer, D.B., \& Franklin, J.F. (2002) Conserving forest biodiversity: a comprehensive multiscaled approach. Island Press, Washington.

Lindenmayer, D.B., Hobbs, R.J., Likens, G.E., Krebs, C. \& Banks, S.C. (2011) Newly discovered landscape traps produce regime shifts in wet forests. Proc Natl Acad Sci USA 108, 15887-15891.

Lindenmayer, D.B., Knight, E., McBurney, L., Michael, D. \& Banks, S.C. (2010) Small mammals and retention islands: an experimental study of animal response to alternative logging practices. Forest Ecol Manage 260, 2070-2078.

McDermott, C.L., Cashore, B. \& Kanowski, P.J. (2010) Global environmental policies. An international comparison. Earthscan, London.

Martikainen, P., Kouki, J. \& Heikkala, O. (2006) The effects of green tree retention and subsequent prescribed burning on ground beetles (Coleoptera: Carabidae) in boreal pine-dominated forests. Ecography 29, 659-670.

Mascia, M.B. \& Pailler, S. (2011) Protected area downgrading, downsizing, and degazettement (PADD) and its conservation implications. Conserv Lett 4, 9-20.

Merger, E., Dutschke, M. \& Verchot, L. (2011) Options for REDD+ voluntary certification to ensure net GHG benefits, poverty alleviation, sustainable management of forests and biodiversity conservation. Forests 2, 550-557.

Millennium Ecosystem Assessment. (2005) Ecosystems and human well-being: biodiversity synthesis. World Resources Institute, Washington, D.C.

Nyvold, U., Dawson, J.K. \& Hickey, J.E. (2005) An assessment of timber values from alternative silvicultural systems tested in wet Eucalyptus obliqua forest in Tasmania. Tasforests 16, 19-34.

Outerbridge, R.A. \& Trofymow, J.A. (2009) Forest management and maintenance of ectomycorrhizae: a case study of green tree retention in south-coastal British Columbia. BC J Ecosys Manage 10, 59-80.

Paquette, A. \& Messier, C. (2010) The role of plantations in managing the world's forests in the Anthropocene. Front Ecol Environ 8, 27-34.

Pastur, G.J.M., Lencinas, M.V., Cellini, J.M., Peri, P.L. \& Esteban, R.S. (2009) Timber management with variable 
retention in Nothofagus pumilio forests of Southern Patagonia. Forest Ecol Manage 258, 436-443.

Phalan, B., Balmford, A., Green, R.E. \& Scharlemann, J.P.W. (2011) Minimising the harm to biodiversity of producing more food globally. Food Policy 36, S62-S71.

Porter-Bolland, L., Ellis, E.A., Guariguata, M.R., Ruiz-Mallen, I., Negrete-Yankelevich, S. \& Reyes-Garcia, V. (2012) Community-managed forests and forest protected areas: an assessment of the conservation effectiveness across the tropics. Forest Ecol Manage 268, 6-17.

Powers, M.D., Pregitzer, K.S., Palik, B.J. \& Webster, C.R. (2011) The physiological basis for regeneration response to variable retention harvest treatments in three pine species. Forestry 84, 13-22.

Puettmann, K.J., Coates, K.D. \& Messier, C. (2008) A Critique of silviculture. Managing for complexity. Island Press, Washington, D.C.

Putz, F.E., Sist, P., Fredricksen, T. \& Dykstra, D. (2008) Reduced-impact logging: challenges and opportunities. Forest Ecol Manage 256, 1427-1433.

Ranius, T. \& Roberge, J.-M. (2011) Effects of intensified forest on the landscape-scale extinction of dead wood dependent species. Biodivers Conserv 20, 2867-2882.

Ribe, R.G. (2005) Aesthetic perceptions of green-tree retention harvests in vista views: the interaction of cut level, retention pattern and harvest shape. Landscape Urban Plan 73, 277-293.

Roccaforte, J.P., Fule, P.Z. \& Covington, W.W. (2010) Monitoring landscape-scale Ponderosa Pine restoration treatment implementation and effectiveness. Restor Ecol 18, 820-833.

Rosenvald, R. \& Lõhmus, A. (2008) For what, when, and where is green-tree retention better than clear-cutting? A review of the biodiversity aspects. Forest Ecol Manage 255 , $1-15$.

Saatchi, S.S., Harris, N.L., Brown, S. et al. (2011) Benchmark map of forest carbon stocks in tropical regions across three continents. Proc Natl Acad Sci USA 108, 9899-9904.

Schmitt, C.B., Burgess, N.D., Coad, L. et al. (2009) Global analysis of the protection status of the world's forests. Biol Conserv 142, 2122-2130.
Schneider, R.R., Hauer, G., Adamowicz, W.L. \& Boutin, S. (2010) Triage for conserving populations of threatened species: the case of woodland caribou in Alberta. Biol Conserv 143, 1603-1611.

Schulze, M., Grogan, J., Landis, R.M. \& Vidal, E. (2008) How rare is too rare to harvest? Management challenges posed by timber species occurring at low densities in the Brazilian Amazon. Forest Ecol Manage 256, 1443-1457.

Sheil, D., Putz F.E. \& Zagt R.J., editors. (2010) Biodiversity conservation in certified forests. Tropenbos International. ETFRN (European Tropical Forest Research Network) News no. 51 .

Sist, P., Sheil, D., Kartawinata, K. \& Priyadi, H. (2003) Reduced-impact logging in Indonesian Borneo: some results confirming the need for new silvicultural prescriptions. Forest Ecol Manage 179, 415-427.

Smith, E.D. \& Maltby, E. (2003) Using the ecosystem approach to implement the convention on biological diversity: key issues and case studies. Pages 118. Ecosystem management series no. 2. IUCN, Gland, Switzerland and Cambridge, England.

Smith, P., Gregory, P.J., van Vuuren, D. et al. (2010) Competition for land. Philos T R Soc B 365, 2941-2957.

TEEB. (2010) The economics of ecosystems and biodiversity: mainstreaming the economics of nature: a synthesis of the approach, conclusions and recommendations of TEEB. TEEB. Available at: http://www.teebweb.org/TEEBSynthesisReport/tabid/ 29410/Default.aspx.

Vanderwel, M.C., Malcolm, J.R. \& Mills, S.C. (2007) A meta-analysis of bird responses to uniform partial harvesting across North America. Conserv Biol 5 , 1230-1240.

Wintle, B.A. \& Lindenmayer, D.B. (2008) Adaptive risk management for certifiably sustainable forestry. Forest Ecol Manage 256, 1311-1319.

Work, T.T., Jacobs, J.M., Spence, J.R. \& Volney, W.J. (2010) High levels of green-tree retention are required to preserve ground beetle biodiversity in boreal mixedwood forests. Ecol Appl 20, 741-751. 